\author{
Krzysztof Lesiakowski \\ https://orcid.org/0000-0002-6176-6064 \\ Wydział Filozoficzno-Historyczny Uniwersytetu Łódzkiego
}

\title{
Bez porozumienia. Burzliwe spotkanie strajkujących włókniarzy łódzkich z premierem Piotrem Jaroszewiczem w lutym $1971 \mathrm{r}$.
}

\begin{abstract}
Abstrakt: Celem artykułu było przedstawienie rozmów premiera Piotra Jaroszewicza ze strajkującymi robotnikami w Łodzi, do których doszło wieczorem 14 II 1971 r. Władze PRL liczyły, że w trakcie bezpośredniego spotkania uda się doprowadzić do zakończenia groźnego konfliktu. Jaroszewicz nie osiagnął jednak takiego efektu, jak Edward Gierek w Szczecinie i w Gdańsku w styczniu $1971 \mathrm{r}$. W tej sytuacji rząd został zmuszony do wycofania się z grudniowej podwyżki cen.
\end{abstract}

Słowa kluczowe: kryzysy polityczne w PRL, strajki w Polsce po II wojnie światowej, premierzy polscy - Piotr Jaroszewicz, przemysł włókienniczy, Łódź.

Abstract: The main goal of this article was to present the talks of Prime Minister Piotr Jaroszewicz with striking workers in Łódź. The meeting took place in the evening of 14 February 1971. The Polish People's Republic authorities hoped that a direct contact would make it possible to end the dangerous conflict. Prime Minister Jaroszewicz, however, did not achieve the same effect as Edward Gierek in Szczecin and Gdańsk in January 1971. In this situation, the government was forced to withdraw from the December price increase.

Keywords: political crises in People's Poland, strikes in Poland after World War II, Prime Ministers of Poland - Piotr Jaroszewicz, textile industry, Łódź.

Konflikty są wpisane w naturę życia społeczno-politycznego. Jak stwierdził socjolog Alain Touraine, „każde społeczeństwo tłumi, a to co stłumione może powrócić przybierając postać kontestowania stosunków klasowych, a zatem 
do ustanowienia nowej formy historyczności”" która powinna być rozumiana jako działanie społeczeństwa na rzecz przekształcania samego siebie. Poza tym w każdym konflikcie, niezależnie od jego typu, zawsze występuje jeden wspólny element - wyzwanie rzucone władzy². Ich przyczyną będą rozbieżne dążenia, niezaspokojone oczekiwania, poczucie krzywdy itp. ${ }^{3}$ Ta praktyka dotyczy tak ustrojów demokratycznych, gdzie obywatele stosunkowo łatwo mogą występować w obronie swoich, zwykle grupowych interesów, jak i innych reżimów. Z ta jednak różnica, że w ustrojach niedemokratycznych konflikty są ukrywane, ale gdy już się ujawniaja, to mają wyjątkowo duży zasięg i poważne następstwa.

Odnosząc te ogólne uwagi do rzeczywistości panującej w Polsce po II wojnie światowej, a zwłaszcza w okresie pierwszego ćwierćwiecza, należy stwierdzić, że ukrywanie zjawisk konfliktowych ułatwiała kontrola środków przekazu i aparatu administracyjnego państwa przez ośrodek władzy, którym była partia komunistyczna. W efekcie głosy niezadowolenia względnie skutecznie blokowano. Stąd pozornie można powiedzieć, że PRL i inne państwa socjalistyczne były krajami bez konfliktów. Kardynalną zasadę w nich obowiązująca, porządkująca życie publiczne na wszystkich jego poziomach, stanowiła tzw. zasada jedności interesów. Polegała ona na upowszechnianiu przekonania o pełnej harmonii społeczeństwa i władzy, a także różnych grup w obrębie tego społeczeństwa. Ta wspólnota z natury rzeczy miała funkcjonować bez konfliktów politycznych ${ }^{4}$. Utrzymywanie tego stanu ułatwiała blokada możliwości artykulacji interesów innych niż te, które zostały zdefiniowane przez centrum polityczne. Sytuacja ta dotyczyła także napięć na linii robotnicy a państwo, które było właścicielem fabryk w PRL. Z naczelnej zasady jedności, która organizowała życie w państwie, wynikało, że związki zawodowe, które w ustrojach demokratycznych spełniają funkcję reprezentanta świata ludzi pracy, teraz zmieniały swoje miejsce i zadania. Następowało swoiste upaństwowienie związków zawodowych poprzez wmontowanie ich w aparat władzy stworzony przez partię komunistyczna. W efekcie przejmowały one część odpowiedzialności za realizację zadań produkcyjnych, przy jednoczesnym odsunięciu na dalszy plan zabiegów na rzecz ochrony interesów pracowniczych. Było to zgodne z tezą bolszewików, że skoro proletariat sprawuje władzę, a z taką sytuacją formalnie mieliśmy do czynienia także w Polsce po 1945 r., to nie istnieje potrzeba organizowania obrony tegoż proletariatu przed samym sobą ${ }^{5}$. Eliminacja związków zawodowych, czyli instytucjonalnej

\footnotetext{
1 A. Touraine, $O$ socjologii, tłum. M. Warchała, Warszawa 2010, s. 146.

${ }^{2}$ P.T. Coleman, Konflikt a władza, w: Rozwiazywanie konfliktów. Teoria i praktyka, red. M. Deutsch, P.T. Coleman, tłum. M. Cierpisz i in., Kraków 2005, s. 108.

${ }^{3}$ Szerzej na temat przyczyn i typologii konfliktów o charakterze politycznym zob. A. Wojtaszak, Konflikt i jego znaczenie $w$ aspekcie politologicznym, w: Oblicza konfliktów. Zbiór analiz i studia przypadków, red. J.J. Piątek, R. Podgórzańska, Toruń 2008, s. 321-328.

${ }^{4}$ J. Drygalski, J. Kwaśniewski, (Nie)realny socjalizm, Warszawa 1992, s. 157.

${ }^{5}$ Ibidem, s. 62-63.
} 
płaszczyzny rozwiązywania sporów i poszukiwania kompromisów, tworzyła fikcję istnienia naturalnej jedności interesów. Jednak fikcja nie mogła zastąpić rzeczywistości.

W praktyce konfliktów w polskich fabrykach po II wojnie światowej nie brakowało. Strajki - jak stwierdził Padraic Kenney - stawały się w zasadzie jedynym narzędziem, za którego pośrednictwem pracownicy mogli sprawić, że ich żądania zostały szerzej poznane ${ }^{6}$. Okres bezpośrednio po II wojnie światowej dogłębnie pod tym kątem zbadał historyk Łukasz Kamiński. Doliczył się on łącznie 1220 strajków o różnym podłożu $(84,4 \%$ - ekonomiczne, 13,3\% - polityczne, 2,3\% - mieszane). Liczbę uczestników trudno określić tylko w 1946 r. była ona szacowana na 340 tys. ${ }^{7}$ Komentujac te ustalenia, można powiedzieć, że w Polsce występowało zjawisko pozornej harmonii i prawdziwych konfliktów, czego wyraz stanowiły strajki. W kolejnych latach narastająca stalinizacja życia, która skutkowała surowymi represjami i ścisła blokadą możliwości artykulacji głosów niezadowolenia, formalnie oznaczała wyraźne zmniejszenie się liczby otwartych konfliktów w zakładach.

Konsekwencją wprowadzonego w Polsce ustroju społeczno-politycznego była jednak cykliczność zjawisk kryzysowych. Władza polityczna, skoncentrowana na zachowaniu i umacnianiu swojego panowania, prowadziła do braku zaspokojenia potrzeb bytowych i wolności obywateli. To skutkowało - według socjologa Stefana Nowaka - pogłębianiem napięć w warunkach tzw. kryzysu utajonego. Z czasem przechodził on w fazę kryzysu jawnego, który znosił aktualną ekipę rządzącą ${ }^{8}$. Ujawnione konflikty społeczne, np. z 1956 r. czy te z przełomu 1970 i 1971 r., z uwagi na fakt, że zawierały krytykę monopolu partii na wyrażanie woli zbiorowej społeczeństwa, były bardzo groźne dla reżimu, bo uderzały w podstawy ustrojowe. W tej sytuacji władza nastawiała się na ochronę i wzmocnienie swojego panowania, co oznaczało przejście do kolejnej fazy kryzysu utajonego. Działo się tak, pomimo że robotnicy w Poznaniu w pierwszym rzędzie eksponowali niepolityczne hasło „Chcemy chleba”, a ci protestujacy na Wybrzeżu domagali się wycofania się z podwyżek cen. Nawet tego rodzaju żądania groziły jednak destabilizacją systemu, a w perspektywie czasu jego dezintegracja, czego w przyszłości dowiedzie działalność Niezależnego Samorządnego Związku Zawodowego „Solidarność”. Stąd w realiach PRL konflikt wyrosły na podłożu ekonomicznym stawał się wydarzeniem politycznym, gdyż naruszał opisywaną powyżej pozorna harmonię społeczna, zbudowaną wokół osi, którą stanowiła zasada jedności interesów całego społeczeństwa pod kierownictwem PZPR.

\footnotetext{
${ }^{6}$ P. Kenney, Budowanie Polski Ludowej. Robotnicy a komuniści 1945-1950, tłum. A. Dzierzgowska, Warszawa 2015, s. 367.

7 Ł. Kamiński, Polacy wobec nowej rzeczywistości 1944-1948. Formy pozainstytucjonalnego, żywiołowego oporu społecznego, Torun 2000, s. 137-139.

${ }^{8}$ S. Nowak, O Polsce i Polakach, Warszawa 2009, s. 176.
} 
W tej sytuacji warto postawić pytanie, jak aparat władzy radził sobie w warunkach ostrego kryzysu, gdy dotychczasowe sposoby pacyfikowania nastrojów społecznych, takie jak propaganda czy represje, okazywały się niewystarczające. Gdy w powstałej rywalizacji nie jest możliwe zakończenie konfliktu przez zwycięstwo czy wycofanie się jednej ze stron, pozostaje stwierdza się w literaturze politologicznej - kooperacja polegająca na przyjęciu postawy nastawionej na kompromis ${ }^{9}$. W sierpniu 1980 r. doszło do podpisania słynnych porozumień społecznych, które stanowiły zaprzeczenie dotychczasowego modelu postępowania w tego rodzaju sytuacjach: „Po raz pierwszy w PRL władza w swojej istocie totalitarna, dysponująca wszystkimi środkami, zgodziła się na ograniczenia wyznaczone przez swoich poddanych" ${ }^{10}$ napisał Aleksander Łuczak. Pamiętać jednak trzeba, że już z zakończenia rewolty robotniczej z grudnia 1970 r. można wyciagnąć wnioski, że nie tylko argument siły będzie rozstrzygający w sytuacji konfliktowej ${ }^{11}$. Chodzi tutaj o spotkania nowego I sekretarza PZPR Edwarda Gierka z reprezentacja strajkujących robotników w Szczecinie i Gdańsku w 1971 r. ${ }^{12}$ Słynny apel szefa partii o pomoc w realizacji nowej polityki wywołał pozytywny odzew. Podkreślić jednak trzeba, że spotkania te (zwłaszcza to w Gdańsku) odbywały się w momencie, gdy minęła najostrzejsza faza konfliktu, a skład delegacji robotniczej trudno uznać za reprezentatywny. Tymczasem w 1956 r. bunt społeczny w Poznaniu krwawo stłumiono, a przybyli wtedy do stolicy Wielkopolski reprezentanci władz partyjnych i państwowych, z premierem Józefem Cyrankiewiczem na czele, koncentrowali się na skutecznym zlikwidowaniu wystapień. Władza nie szukała kompromisu, czego najlepszym dowodem sa haniebne słowa premiera, zawierające groźbę odrąbywania rąk podniesionych na władzę ludową ${ }^{13}$. Z tego zestawienia wynika, że teza o harmonii między władzą a społeczeństwem w dłuższej perspektywie czasu była nie do utrzymania. Musiały jednak upłynąc długie dziesięciolecia, zapisane krwawymi kartami, aby PZPR uznała, że jedność interesów to mrzonka, a kompromis konieczny warunek skutecznego rządzenia.

W nawiązaniu do przedstawionego powyżej ogólnego kontekstu historycznego warto się zastanowić, czy łódzkie doświadczenia z okresu powojennego

${ }_{9}$ A. Wojtaszak, op. cit., s. 329.

${ }_{10}$ A. Łuczak, Dekada polskich przemian. Studium władzy i opozycji, Warszawa 2012, s. 198.

${ }^{11}$ Wspomnieć trzeba, że i w przeszłości, w znacznie mniejszej skali, takie próby już podejmowano. Można tu np. wymienić bezpośrednie rozmowy kierownika Ministerstwa Gospodarki Komunalnej ze strajkujacymi tramwajarzami w Łodzi w sierpniu 1957 r.

${ }^{12}$ M. Paziewski, Debata robotników z Gierkiem. Szczecin 1971, Warszawa 2010, s. 60-82; J. Eisler, Grudzień 1970. Geneza, przebieg, konsekwencje, Warszawa 2000, s. 350-351.

${ }^{13}$ Komisja pod kierownictwem Gierka przygotowała też raport z wydarzeń poznańskiego Czerwca, który został przedstawiony 7 VII 1956 r. podczas narady w KC PZPR. Padły w nim słowa o tym, że „wydarzenia poznańskie miały charakter wrogiej, antyludowej dywersji i prowokacji politycznej”. Zob. Poznański Czerwiec 1956. Wybór dokumentów, t. I, oprac. S. Jankowiak, R. Kościański, E. Makowski, R. Reczek, Poznań 2012, s. 205. 
moga być pomocne w znalezieniu dowodu dotyczacego stopniowego rozpadu doktrynalnej tezy o jedności interesów władzy i społeczeństwa.

Bezpośrednio po wojnie Łódź stanowiła wiodący ośrodek strajkowy w kraju. W latach 1945-1948 nieco ponad 40\% wszystkich strajków w Polsce zanotowano w tym właśnie mieście. Do początku lat pięćdziesiątych było to ponad 530 strajków. Jeden z nich miał miejsce nawet w $1951 \mathrm{r}$. Nową falę dało się dostrzec w latach 1956-1959, z których najpoważniejszy był strajk tramwajarzy w dniach 12-13 VIII $1957 \mathrm{r}$. W tym okresie można się doliczyć ok. 30 strajków $^{14}$. Kolejna fala wystapień strajkowych w tym mieście nastapiła dopiero na początku 1971 r., ale miała ona zwiazek z rewolta na Wybrzeżu w grudniu 1970 r. Wspomnieć jednak należy, że w dniach grudniowego kryzysu odnotowano także kilka krótkotrwałych „przerw w pracy”. Fali strajków z lutego następnego roku trzeba się nieco szerzej przyjrzeć z uwagi na towarzyszacce im wydarzenia, związane z aktywnością władz PRL obliczoną na likwidację strajku.

Jako pierwsze przed południem 10 II 1971 r. zastrajkowały Łódzkie Zakłady Obuwia „Stomil”, a po nich na styku I i II zmiany przerwało prace ok. 300 osób z przędzalni odpadkowej Zakładów Przemysłu Bawełnianego im. Juliana Marchlewskiego (ZPB). W tej drugiej firmie produkcja nie została wznowiona do końca dnia, jak i w ciagu następnej doby. Przyczyną strajku stały się informacje, iż styczniowe zarobki będą niższe w stosunku do grudniowych o 200-300 zł. Wydana pod naciskiem robotników decyzja dyrekcji o przyspieszeniu wypłaty z 15 lutego na 12 lutego potwierdziła wcześniejsze obawy. Fakt ten musiał spowodować dalsze zaostrzenie się sytuacji. Po podwyżce cen żywności z grudnia 1970 r. niższe zarobki za styczeń $1971 \mathrm{r}$. stawiały wielu robotników w dramatycznej sytuacji. Na to nałożyły się emocje powstałe pod wpływem informacji telewizyjnej o rzekomej podwyżce płac dla stoczniowców. W tej sytuacji włókniarze zażądali dla siebie $20 \%$ podwyżki. Temu głównemu postulatowi towarzyszył szereg innych szczegółowych żądań stworzenie przejrzystego sposobu naliczania płac, uczciwy podział premii eksportowej itp.

Począwszy od 12 lutego, strajk ogarnał całe ZPB (pracowało tu 8,2 tys. osób), a co ważniejsze, do akcji protestacyjnej zaczęły się przyłączać inne zakłady. Najpierw stanęła branża bawełniana - praktycznie cała, w trzech zakładach, które jeszcze pracowały, notowano tak wielkie napięcie, że strajk był kwestia czasu. Ogółem na krócej lub dłużej zatrzymano produkcję w nie mniej niż 40 łódzkich zakładach (10 bawełnianych, 8 wełnianych, 4 dziewiarskich i pończoszniczych, 2 jedwabniczo-pasmanteryjnych, 3 elektrotechnicznych, 4 przemysłu maszynowego, 9 innych branż). Łączne zatrudniały one ponad 107 tys. pracowników i choć nie wszyscy z nich strajkowali,

${ }^{14}$ Ł. Kamiński, op. cit., s. 137; K. Lesiakowski, Strajki robotnicze w Eodzi 1945-1976, Łódź 2008, s. 260. 
to ze skrupulatnych zestawień wytworzonych przez SB (z podziałem na poszczególne firmy) wynika, że od maszyn odeszło 60,5 tys. osób. Ta duża liczba musiała robić wrażenie. Niewątpliwie stawała się czynnikiem politycznym, który wymagał od rządzących adekwatnych działań. Fikcyjność zasady jedności interesów władzy i społeczeństwa, w tym wypadku pracowników łódzkich fabryk włókienniczych i innych, była aż nadto widoczna. Ponieważ $\mathrm{w}$ tym czasie nie istniało $\mathrm{w}$ Polsce prawo dotyczące strajków ${ }^{15}$, a tym samym określone ustawowo reguły rozwiąywania tego rodzaju konfliktów, w grę wchodziły użycie siły na dużą skalę (w tym momencie raczej nierealne) lub nadzwyczajne działania polityczne, takie jak negocjacje ze strajkujacymi.

Początkowo nic nie wskazywało na to, że kroki polityczne zostana podjęte. Władza usiłowała reagować w sposób rutynowy i bez specjalnej energii. Świadczy o tym spotkanie dyrektora ZPB Zbigniewa Balawajdera, przedstawicieli Komitetu Zakładowego (KZ) PZPR i związków zawodowych ze strajkującymi. Rozmowy jednak nic nie dały.

Wtedy do działań przystapiła delegacja władz centralnych, w której skład wchodzili: wicepremier Jan Mitręga, minister przemysłu lekkiego Tadeusz Kunicki, przewodniczący Centralnej Rady Związków Zawodowych Władysław Kruczek oraz I sekretarz Komitetu Łódzkiego (KŁ) PZPR Józef Spychalski i przewodniczący Prezydium Rady Narodowej m. Łodzi Edward Kaźmierczak. Jednak dopiero pod naciskiem strajkujących, w nocy z 12 na 13 lutego, urzędnicy ci zdecydowali się na bezpośrednie spotkanie z robotnikami, a nie tylko z ich delegatami. Można w tym miejscu - za pisarzem i socjologiem Bronisławem Świderskim - powiedzieć, że zaznaczyło się wtedy zjawisko demokracji bezpośredniej, niespotykane w PRL - jednostki mogły aktywnie i konsekwentnie wyrażać swoje postulaty ${ }^{16}$.

Ogółem w trakcie spotkania zabrało głos ok. 40 osób spośród strajkującej załogi ZPB, które przedstawiły następujące postulaty: cofnięcie przyznanych w styczniu dodatków dla najniżej zarabiajacych przy jednoczesnym przywróceniu starych cen na artykuły żywnościowe, usunięcie istniejącego bałaganu organizacyjnego w zakładach, lepsze traktowanie robotników przez średni personel techniczny, poprawa warunków socjalnych i bhp ${ }^{17}$. Wybrzmiało też żądanie spotkania z I sekretarzem Komitetu Centralnego (KC) PZPR, w czym upatrywać należy nawiązania do niedawnych głośnych rozmów w Szczecinie

${ }^{15}$ Dopiero w porozumieniach sierpniowych z 1980 r. strajk został wymieniony jako dopuszczalny środek obrony interesów pracowniczych. Zob. W. Kulesza, Demonstracja. Blokada. Strajk (Granice wolności zgromadzeń $i$ strajku w polskim prawie karnym na tle prawa niemieckiego), Łódź 1991, s. 196.

16 B. Świderski, Gdańsk i Ateny. O demokracji bezpośredniej w Polsce, Warszawa 1996, s. 9, 77.

17 Archiwum Instytutu Pamięci Narodowej Oddział w Łodzi (dalej: AIPN Łd), 10/770, Meldunek płk. H. Tomaszewskiego, zastępcy komendanta miejskiego MO ds. SB w Łodzi, 13 II 1971 r., k. 352. 
i Gdańsku. Tymczasem wicepremier i jego współpracownicy na te żądania odpowiadali jedynie zapewnieniami o braku możliwości ich spełnienia, wzywając do niezwłocznego przystapienia do pracy. Jedynym gestem z ich strony był apel o wyłonienie delegacji robotniczej, która w Warszawie przeprowadziłaby dalsze rozmowy. Po doświadczeniach gdańsko-szczecińskich takie zaproszenie musiało zostać odrzucone. „My pojedziemy wszyscy do Warszawy. Delegację nam zamkna, a co damy naszym dzieciom jeść - suchy chleb?" - pytała jedna ze strajkujących włókniarek. Z każdą chwilą napięcie rosło. Przywołanie przez ministra Kunickiego informacji o tym, że w związku z grudniową zmiana cen niektóre towary, w tym rajtuzy dla dzieci, potaniały, spotkało się z natychmiastowa riposta jednej z uczestniczek tego spotkania: „Panie ministrze, co pan będzie owijał w bawełnę [...]. Proszę pana, czy ja swemu dziecku rajtuzy w usta wsadzę i będzie je ciągnęło jak gumę do żucia"18. Gdy głos zabrał przywódca reżymowych związków zawodowych Kruczek, emocje sięgnęły zenitu i przybrały - jeśli wierzyć wspomnieniom Mieczysława Rakowskiego - zgoła nieparlamentarna formę, jednocześnie bardzo dosadnie wyrażająca stosunek strajkujących do „czerwonej” władzy. Wzburzona włókniarka uniosła spódnicę i pokazała tyłek ${ }^{19}$. Nie ulega wątpliwości, że to „przewrotne podsumowanie dotychczasowego etapu negocjacji” oznaczało ich totalną klapę.

Została zarządzona przerwa w rozmowach. Delegaci z Warszawy udali się tymczasem na naradę do KZ PZPR w ZPB, a następnie - możliwe, że nie będąc pewni swojego bezpieczeństwa - przenieśli się do siedziby Kł. Tymczasem robotnicy do rana czekali w zakładowej świetlicy na decyzję o odwołaniu grudniowej podwyżki. Później poszli do kasy i odebrali zarobki za styczeń, jak wspomniano, niższe średnio o $200 \mathrm{zł}$ niż w poprzednim miesiącu. Najpewniej w tym krytycznym momencie trwały konsultacje wicepremiera Mitręgi i osób mu towarzyszących z Warszawa, gdyż w strajkujacych fabrykach pojawili się oni dopiero po południu 13 lutego. Wicepremier Mitręga i przewodniczący Kruczek w ZPB, a minister Kunicki w zakładzie „A” Łódzkich Zakładów Przemysłu Bawełnianego im. Obrońców Pokoju (ŁZPB). Z dostępnych źródeł jasno nie wynika, czy przedstawili nowe stanowisko strony rządowej (pośrednio można tak przypuszczać), nie ma nawet pewności, czy spotkali się bezpośrednio ze strajkującymi robotnikami, a nie kontaktowali się z nimi przez aktywistów partyjnych. Zapewne tylko szef resortu przemysłu lekkiego odbył otwarte spotkanie z pracownikami. Był jednak na tyle nieprzekonujący, że na oddziale, na którym się pojawił - dodajmy dotąd pracującym - zdecydowano

\footnotetext{
18 Archiwum Państwowe w Łodzi (dalej: APŁ), Komitet Łódzki Polskiej Zjednoczonej Partii Robotniczej (dalej: KŁ PZPR), 45, Sytuacja w ZPB im. J. Marchlewskiego, 12 II 1971 r., k. 117; Grudzień 1970, Paryż 1986, s. 551.

${ }^{19}$ M. Matys, Kto pokazat tytek Jaroszewiczowi?, w: P. Lipiński, M. Matys, Absurdy PRL-u, Warszawa 2014, s. 37-38; „Dziennik Łódzki”, 11 II 1991, s. 3; „Życie”, $17-18$ II 2001, s. 15; M.F. Rakowski, Dzienniki polityczne 1969-1971, Warszawa 2001, s. 361.
} 
się na utworzenie komitetu strajkowego i okupację budynku ${ }^{20}$. W warunkach impasu negocjacyjnego wiodąca w strajku załoga ZPB zażądała przyjazdu do Łodzi I sekretarza KC PZPR Gierka ${ }^{21}$. Niezmiennie oczekiwano też podwyżki płac na poziomie 250 zł. Aby zwiększyć nacisk na władzę, zapowiedziano podjęcie w całej fabryce strajku okupacyjnego. Wśród części strajkujących, głównie osób młodszych wiekiem, zaczęły się też pojawiać głosy o zamiarze przeniesienia protestów na ulice. Taki rozwój wypadków mógł być dla rządzących bardzo groźny.

Mimo że łódzki konflikt zaczynał coraz silniej zagrażać narastaniem destabilizacji w Łodzi i ewentualnie w kraju, można byłoby tu powiedzieć za Ralfem Dahrendorfem, że stawał się „narzędziem zmiany przez destabilizację"22. Tymczasem Gierek nie podją wyzwania i nie przybył osobiście do Łodzi. Trudno powiedzieć, dlaczego tak się stało? Może miał inne obowiązki lub jego elastyczność i pewna oryginalność w działaniu już się wyczerpały po spotkaniach w Szczecinie i Gdańsku? Możliwe, że w roli „strajkowego strażaka” zaczał dostrzegać dewaluację swojej pozycji i władzy. Z perspektywy czasu widać, że to był błąd I sekretarza. Żadna inna osoba z jego ekipy $\mathrm{w}$ tym czasie nie dysponowała tak dużym kapitałem zaufania w oczach opinii społecznej. Jeśli więc zamierzano podjąć zabiegi na rzecz odbudowy mirażu jedności interesów między władzą a społeczeństwem, nie mogło się to udać bez jego udziału, choć oczywiście nie było gwarancji, że jego przyjazd zakończyłby się sukcesem. Świadczą o tym słowa robotnika z ZPB z okresu strajku, że jak ,tow. Gierek przyjedzie i nic nie zrobi to będzie tak samo jak jest teraz" ${ }^{23}$. Tymczasem wyznaczony do rozmów ze strajkującymi nowy premier - Piotr Jaroszewicz nie był dobrym wyborem. Poza ważną funkcja, która sprawował, trzeba odnotować, że chodziło tu o byłego wojskowego z pionu wychowawczego, partyjno-rządowego biurokratę, osobę pozbawiona walorów agitatora politycznego. Bez zdecydowanych ustępstw wobec strajkujących Jaroszewicz nie miał szans na powtórzenie sukcesu Gierka, przez co należy rozumieć zakończenie strajku na warunkach akceptowalnych przez władzę.

Swój pobyt w Łodzi Jaroszewicz rozpoczął od próby zmobilizowania tzw. aktywu partyjnego, ze szczególnym uwzględnieniem działaczy szczebla zakładowego. To miał być swoisty bufor w nieuniknionym zderzeniu ze strajkującymi robotnikami. Ich rolą było zwielokrotnienie wśród załóg słów premiera o braku możliwości spełnienia postulatów płacowych bez szkody dla

${ }^{20}$ Fakt ten miał miejsce 14 II 1971 r. na oddziale przędzalni odpadkowej ŁZPB. Zob. Strajki tódzkie $w$ lutym 1971. Geneza, przebieg i reakcje władz, oprac. E. Mianowska, K. Tylski, Warszawa-Łódź 2008, s. 164; AIPN Łd, 10/769, Informacja nr 18, 14 II 1971 r., k. 265.

${ }^{21}$ APŁ, KŁ PZPR, 547, Informacja nr 22/71, 13 II 1971 r., s. 130.

${ }^{22}$ R. Dahrendorf, Klasy i konflikt klasowy w społeczeństwie przemystowym, tłum. R. Babińska, Kraków 2008, s. 147.

${ }^{23}$ APŁ, KŁ PZPR, 45, Sytuacja w ZPB im. Marchlewskiego, 12 II 1971 r., k. 118. 
równowagi gospodarczej kraju. Choć aktywiści formalnie wykazywali zrozumienie dla tej tezy i deklarowali wsparcie dla polityki nowego kierownictwa partyjnego i rządowego, to jednak nie zabrakło rozmaitych głosów krytycznych ${ }^{24}$. Część z nich znacznie wykraczała poza deklarację przedstawiciela Zakładów Przemysłu Pończoszniczego im. Wacława Jurczaka, który skończył swoje wystapienie słowami: „Pomożemy Wam towarzysze w realizacji zadań produkcyjnych, ale prosimy nie zapominać o klasie robotniczej”25. Przedstawicielka zakładów azbestowych zwracała zatem uwagę na dramatycznie niskie płace: „gdyby tak towarzysze swoim żonom dali tyle pieniędzy ile nam mężowie daja, to dopiero zobaczyliby jak żona się gospodarzy i jak nie może koniec z końcem związać". Poza tym utyskiwano na swoiste wyalienowanie się wyższych władz partyjnych i kadry zarządzającej fabrykami oraz zjednoczeniami ze środowiska robotniczego (,Zbliżyć się towarzysze do mas, nie bać się ich, one nie gryza, one są tylko rozżalone"). Nie zabrakło też krytyki polityki państwa wobec Łodzi, zaniedbywania inwestycji w infrastrukturę komunalną i modernizację zakładów przemysłowych - w odniesieniu do tej ostatniej kwestii jeden z mówców podkreślił, że w mieście bez zrozumienia przyjęto wybudowanie i uruchomienie w $1970 \mathrm{r}$. kombinatu włókienniczego w Białej Podlaskiej „Biawena”, „gdzie nie ma ani fachowców, ani wydajności, ani rentowności”" ${ }^{26}$. Szczególną jednak wymowę miały wystapienia sekretarzy PZPR $\mathrm{z}$ wiodacych $\mathrm{w}$ strajku fabryk: im. Juliana Marchlewskiego i im. Obrońców Pokoju. Obaj nie ukrywali obrazu sytuacji w swoich zakładach - pierwszy informował zgromadzonych o pogłoskach, z których wynikało, że protest może się przenieść z fabryk na ulice, a drugi przedstawił postulaty strajkujacych z macierzystego przedsiębiorstwa (w tym $25 \%$ podwyżki płac) i nieco chaotycznie (możliwe, że z lęku przed premierem) prosił rząd „o zrozumienie naszych potrzeb i bezzwłoczne załatwienie wymienionych postulatów"27.

Premier Jaroszewicz nie podjął jednak dyskusji z głosami aktywistów partyjnych. Z tego wynika, że trwał na stanowisku, iż podwyżki płac z przyczyn ekonomicznych są niemożliwe do zaakceptowania przez rząd ${ }^{28}$. Nie wezwał też otwarcie uczestników zgromadzenia do wsparcia polityki kierownictwa

${ }^{24}$ To oznaczało, że lista osób zabierających głos była odpowiednio wyselekcjonowana i zabrakło na niej autentycznych liderów strajkowych. Zob. ibidem, 14, Protokół z posiedzenia plenarnego KE, 16 II 1971 r., k. 7.

${ }^{25}$ AIPN Łd, 10/808, Stenogram z przemówienia Zdzisława Białosińskiego z Zakładów im. Jurczaka, 14 II 1971 r., k. $75 \mathrm{v}$.

${ }^{26}$ Ibidem, Stenogram wystapienia Józefy Żabolickiej z zakładów im. Struga, 14 II 1971 r., k. 55, 56v; ibidem, Stenogram przemówienia sekretarz Krystyny Sobczak z zakładów „Azbest”, 14 II 1971 r., s. 69.

${ }^{27}$ Ibidem, Stenogram przemówienia Dukata [imienia nie ustalono] z zakładów im. Obrońców Pokoju, 14 II 1971 r., k. 58-59v; ibidem, Stenogram z przemówienia Stanisława Komorowskiego z zakładów im. Marchlewskiego, 14 II 1971 r., k. 60v.

${ }^{28}$ Ibidem, Stenogram wystapienia premiera Piotra Jaroszewicza, 14 II 1971 r., k. 65. 
partyjno-rządowego poprzez przywołanie gierkowskiego apelu: „pomożecie?”29. Trzeba jednak zauważyć, iż w tym czasie kolportowano wśród robotników, a pewnie także między uczestnikami spotkania w Teatrze Wielkim, ulotkę z hasłem: „Gierek pyta - pomożecie? Co mu odpowiadasz włókniarzu?” ${ }^{30}$. Brak elastyczności w postawie premiera podczas rozmowy z partyjnymi aktywistami pozwalał sądzić, że dyskusja ze strajkujaccymi na ich terenie, w fabrykach, będzie jeszcze trudniejsza. Należy jednak docenić fakt, że zdecydował się na taki niepewny krok - otwarte rozmowy z setkami protestujących osób, a nie tylko z ich delegatami.

Tymczasem robotnicy w ZPB autentycznie czekali na Jaroszewicza i dlatego nie wysłali swoich przedstawicieli na wspomniane zgromadzenie $\mathrm{w}$ teatrze. Jednocześnie niektórzy spośród tych, którzy brali udział w okupacji zakładu, formułowali wręcz groźby karalne pod adresem spodziewanych delegatów z Warszawy: ,jak przyjada te dygnitarze to skur... łby poobrzynaja” ${ }^{31}$. Zdecydowanie przeważał jednak nastrój niepewności przenikniętej wielką determinacja.

Spotkanie Jaroszewicza, Józefa Tejchmy, Kruczka, Jana Szydlaka, Mitręgi, Mariana Kulińskiego z włókniarzami z ZPB rozpoczęło się 14 II 1971 r. po godz. 19. w zakładowej świetlicy (sali konferencyjnej) sasiadującej z otwarta szatnia. Uczestniczyło w nim ponad tysiąc, a według innych danych nawet 2 tys. osób ${ }^{32}$. Gości przywitano Mazurkiem Dabrowskiego. Sa też informacje, że najpierw odśpiewano znaną bojową i - mówiąc współczesnym językiem antyestablishmentową pieśń $O$ cześć wam panowie, magnaci, a dopiero później rozległ się hymn ${ }^{33}$. Spotkanie prowadził dyrektor zakładu Balawajder. „Goście byli tak zasłonięci osobami stojącymi na krzesłach i zbitymi w tłumie wokół podium, że ktoś stojący na środku sali nie widział, co się dzieje w prezydium". Te okoliczności stworzyły specjalną atmosferę, pełną napięcia. Wszyscy byli wyraźnie podenerwowani. W materiałach źródłowych zwraca się uwagę na emocje udzielające się zwłaszcza robotnicom. Tymczasem mężczyźni mieli się zachowywać „raczej spokojnie i większość z nich siedziała na pulpicie otaczającym szatnię. Wszyscy oczywiście byli w strojach roboczych i mówili absolutnie to co myśla, często kłócąc się między sobą na temat różnych padajacych z trybuny, z ust ich koleżanek bądź kolegów, sformułowań” ${ }^{34}$.

${ }^{29}$ Po latach taka opinia, łącznie z informacją o rzekomej odpowiedzi „nie”, którą miał usłyszeć premier od aktywistów partyjnych, pojawiła się w artykule prasowym. Zob. „Dziennik Łódzki”, 10-11 II 1996, s. 21.

${ }^{30}$ APŁ, KŁ PZPR, 1892, Ulotka, [1971 r.], k. 347.

${ }^{31}$ AIPN Łd, 10/808, Wyciag z dziennika sztabu dotyczący wydarzeń na terenie Łodzi w lutym 1971 r., k. 73.

${ }^{32}$ O 2 tys. uczestników donosił w meldunku z godz. 20. płk Henryk Tomaszewski, szef łódzkiej SB. Ibidem, 10/770, Meldunek o sytuacji na terenie m. Łodzi, 14 II 1971 r., k. 233.

${ }^{33}$ K. Lesiakowski, Strajki robotnicze..., s. 301; Grudzień 1970..., s. 552; A. Woźnicki, Eódzkie strajki, „Solidarność Ziemi Łódzkiej” 1981, nr 7, s. 1.

${ }^{34}$ APŁ, K£ PZPR, 1892, Spotkanie w ZPB im. Marchlewskiego 14 II 1971 r. w sali konferencyjnej od godz. 19-ej do 23.30, k. 160. 
Na początek zabrał głos Jaroszewicz, który mniej więcej powtórzył to, co mówił w Teatrze Wielkim. W efekcie jego obszerne przemówienie od początku przerywały głosy z sali, śmiech i krzyki. Był to znaczący komentarz do słów premiera, który zaczą wystapienie od przypominania tego, co nowe kierownictwo zrobiło w okresie swoich niespełna dwumiesięcznych rządów. Mówił o stratach, które przynosił każdy dzień strajku i deklarował stopniową poprawę sytuacji płacowej w przemyśle lekkim. Sala się nieco wyciszyła, gdy stwierdził, że żaden rząd w Polsce się nie utrzyma „przy niezgodzie z klasą robotnicza, jeżeli nie zaufacie Gierkowi to będzie inny”. Komunikat ten należało odczytać w ten sposób, że będzie to ktoś gorszy, może z poprzedniej ekipy. Takiego rozwoju wydarzeń z pewnością nie oczekiwali strajkujący. Stąd ich pewne zawahanie i wyciszenie. Tego wattku premier jednak nie kontynuował i - jak się okazało - nie wykorzystał momentu nawiązania względnego porozumienia z robotnikami. Stwierdził bowiem jednocześnie zdecydowanie i bardzo otwarcie, że nie istniały możliwości spełnienia najważniejszego postulatu strajkujących - podwyżek płac. Przez swoją nieugiętość i brak wyczucia chwili mówca stracił wszelki kontakt ze strajkującymi ${ }^{35}$. Robotnicy nie chcieli już słuchać premiera, który z uwagi na duży szum na sali podnosił do góry ręce i usiłował uciszać zgromadzonych. Następnie, po napiciu się wody, znów apelował o podjęcie pracy:

Wiem, że straciliście zaufanie, sa to skutki tej niedobrej polityki jaka była, ale trzeba
przecież to przełamać, potrzebna jest praca (krzyk nie!), to do czego doprowadzicie
(odpowiedź [z sali]: do gruźlicy), będziemy strzec waszych interesów jak oka w gło-
wie, sprawa, podjęcia pracy to sprawa waszego sumienia. Najłatwiej krzyczeć „nie”,
my nie mówimy „nie”, dajemy wam gwarancję (żądamy podwyżki - krzyczy sala).
Środki na podwyżki wy sami tworzycie. Powiedziałem wam wszystko, co jako szef
rządu mogłem powiedzieć ${ }^{36}$.

To oznaczało, że strajkujący i władza byli po przeciwnych stronach barykady. Próby premiera odwrócenia sytuacji, głównie za sprawą usilnej prośby o zaufanie, tylko pogłębiały niezadowolenie zgromadzonych.

Następnie głos został oddany strajkujacym. W tym posunięciu trzeba widzieć spora dozę odwagi delegacji rządowej, gdyż nie mogła się ona spodziewać innych niż krytyczne wypowiedzi. Zwykle były to spontaniczne, bardzo emocjonalne głosy, czasem niedokończone z uwagi na płacz mówiącego. Ale przez tę swoją specyfikę stanowiły mocne odzwierciedlenie stanu świadomości strajkujących.

${ }_{35}$ Strajki tódzkie..., s. 166.

36 APŁ, KŁ PZPR, 1892, Opis przebiegu spotkań z włókniarzami w nocy 14 II 1971 r., [1971 r.], k. 139-140. Zob. też: AIPN Łd, 10/808, Informacja o spotkaniu przedstawicieli centralnych władz partyjnych i państwowych z częścią załogi ZPB im. Marchlewskiego w Łodzi, 14 II 1971 r., k. 78; K. Lesiakowski, Premier u włókniarek. Strajki dwa miesiqce po Grudniu '70, „Gazeta Łódzka” (dodatek „Gazety Wyborczej”), 12 II 2001, s. 8. 
Najczęściej w swoich wypowiedziach nawiązywali oni do kwestii niskich płac, co przekładało się na ponawiane żądanie podwyżki o co najmniej $20 \%$. W takich momentach sala reagowała żywiołowo, dopingując mówców oklaskami i werbalnie. Do tego dochodziły różne szczegółowe sprawy będące konsekwencja marnych zarobków, w tym problem dysproporcji wysokości zarobków między robotnikami a urzędnikami fabrycznymi czy niewłaściwych stosunków międzyludzkich w fabryce ${ }^{37}$.

Gorzkim słowom o niskich płacach i skromnym poziomie życia towarzyszyło wiele komentarzy dotyczących koszmarnych warunków pracy. W tym wypadku zwracano uwage na nadmierny hałas, ciasnotę, duchotę i wilgotność, panujące na halach produkcyjnych. Wielu strajkujących podkreślało fatalną organizację pracy, brak części zamiennych do maszyn oraz surowców odpowiedniej jakości, co znów przekładało się na poziom wykonania norm i w konsekwencji mniejsze zarobki ${ }^{38}$. Z tego wynika, że rachunek krzywd, który włókniarze łódzcy przedłożyli premierowi, był długi i bardzo gorzki.

Z części wystapień dało się wyczytać strach przed ewentualnymi represjami. Było to zrozumiałe z uwagi na świeżą pamięć o dramatycznych wydarzeniach na Wybrzeżu. Dlatego domagano się niewyciagania konsekwencji w stosunku do strajkujacych i odpowiednich gwarancji na piśmie. Nie skrywano też nieufności wobec władzy, w tym samego premiera Jaroszewicza, któremu przedstawiciel tkalni z ZPB otwarcie zadał zasadnicze pytanie: „tow. Jaroszewicz - mówicie o Gomułce a gdzie wyście [wcześniej] byli?”39. Jeszcze ostrzej krytykowano lokalne władze partyjne i fabryczne.

W kolejnej fazie spotkania głos znów zabrali przedstawiciele delegacji z Warszawy. Najpierw Szydlak złożył zapewnienie, że nie będą wyciagane żadne konsekwencje w związku z udziałem w strajku. Później mówił o załatwianiu zgłoszonych postulatów „krok po kroku”, po zakończeniu akcji protestacyjnej. Jednak nic nie uzyskał tymi argumentami, bo na słowa: „chcę wrócić do Warszawy i powiedzieć tow. Gierkowi, że włókniarki nie tylko klaszcza jak jest o nim mowa, ale i to, że przystapiły do pracy”, zgromadzeni zwartym chórem odpowiedzieli: „nie” ${ }^{40}$. Podobnie nic nie osiagną minister Kunicki, który oficjalnie oświadczył załodze ZPB, że z powodu strajku nie będa jej groziły żadne kary. Wtedy głos ponownie zabrał premier Jaroszewicz. Występując bardzo koncyliacyjnie, podkreślając szacunek do strajkujących i chęć stosowania dialogu jako metody rozwiązywania zjawisk konfliktowych,

${ }^{37}$ K. Lesiakowski, Strajki robotnicze..., s. 303; Strajki tódzkie..., s. 166.

38 APŁ, KŁ PZPR, 1892, Opis przebiegu spotkań z włókniarzami w nocy 14 II 1971 r., k. 143.

39 W latach 1956-1970 Jaroszewicz był wicepremierem, stałym przedstawicielem PRL w Radzie Wzajemnej Pomocy Gospodarczej oraz przewodniczącym Komitetu Współpracy Gospodarczej z Zagranica przy Radzie Ministrów. Zob. T. Mołdawa, Ludzie władzy 1944-1991. Władze państwowe i polityczne Polski wedtug stanu na dzień 28 II 1991, Warszawa 1991, s. 364.

40 APŁ, KŁ PZPR, 1892, Spotkanie w ZPB im. Marchlewskiego 14 II 1971 r. w sali konferencyjnej od godz. 19-ej do 23.30, k. 161-162. 
na koniec usiłując nieco naśladować Gierka w czasie spotkania ze stoczniowcami, postawił sprawę zakończenia strajku w następujacy sposób: „Chcę Was zapytać czy nas poprzecie? Chór głosów z sali: «tak»! Czy podejmiecie prace - chór głosów z sali: «nie»! My nie mamy i nie chcemy stosować innej metody jak rozmowa z Wami. Prosimy Was o rozwage i przystapienie do pracy. Chór głosów z sali: «nie»!"41.

Całe spotkanie przebiegało w nerwowej atmosferze. Zdarzały się zasłabnięcia wśród zgromadzonych, w tym dyrektora Balawajdera, przerywano wystapienie Szydlaka, ktoś usiłował wyrwać mikrofon przemawiajacemu premierowi. W tej sytuacji widoków na porozumienie nie było żadnych. Z uwagi na powstałe zamieszanie ok. godz. 23 delegację rządową należało wycofywać z zakładowej świetlicy. Dla porównania w Szczecinie, kilka tygodni wcześniej, delegację z Gierkiem na czele żegnano owacją na stojąco! ${ }^{42}$

Niezrażony niepowodzeniem w ZPB w nocy z 14 na 15 lutego premier Jaroszewicz wraz z towarzyszącymi mu osobami jeszcze dwukrotnie konfrontował się z robotnikami ${ }^{43}$. Najpierw ze strajkujacymi z tkalni automatycznej, a następnie wykończalni, największej łódzkiej fabryki - ŁZPB. W obu przypadkach robotnicy nie okazali specjalnej kurtuazji wobec władzy, widząc w niej czynnik odpowiedzialny za swoje trudne położenie życiowe. Mimo to można przyjąć, że w tej fabryce było mniej nerwowo.

Całe spotkanie w „Obrońcach Pokoju” [chodzi o oddział wykończalni - K.L.] przebiegało
w atmosferze spokojnej i rzeczowej. Bardzo niewiele było głosów demagogicznych,
bardzo dużo wstrzasających w swej wymowie. Wstrzasające były też wypowiedzi
premiera i sekretarza [Szydlaka - K.L.], nie sposób jednak oddać tej atmosfery.
Postronnemu słuchaczowi wydaje się, że faktycznie był to dialog z klasa robotniczą
i faktycznie mówiono do ludzi a nie przemawiano. Całe tło zresztą było wstrzasające:
w tkalni C na głowy premiera i sekretarza sypał się tynk, kapała woda, kobiety
były blade, wymęczone, źle wyglądające, zdenerwowane, ale opanowane i stanowcze.
Siedziały i stały na belach tkanin przykrytych by ich nie pobrudzić, stały na maszy-
nach, niektóre starsze spały na tkaninach. Większość słuchała z ogromna nadzieją ${ }^{44}$.

Wśród postulatów przedstawionych premierowi przez pracowników ŁZPB znalazły się m.in. następujące żądania: podwyżka zarobków miesięcznych o 25-30\% tytułem rekompensaty za podniesione ceny artykułów żywnościowych, równy podział premii eksportowej między pracowników fizycznych i umysłowych oraz ustalenie jej najniższej (300 zł) i najwyższej kwoty (1000 zł), uproszczenie skomplikowanego systemu wyliczania płac, stała wymiana osób

${ }^{41}$ Ibidem, k. 164.

${ }^{42}$ M. Paziewski, op. cit., s. 75.

${ }^{43}$ P. Jaroszewicz, B. Roliński, Przerywam milczenie... 1939-1989, Warszawa 1991, s. 171.

${ }^{44}$ APŁ, KŁ PZPR, 1892, Spotkanie w tkalni „C” ŁZPB im. Obrońców Pokoju, 14/15 II 1971 r., k. 159. Zob. też: AIPN Łd, 10/808, Informacja o spotkaniu przedstawicieli centralnych władz partyjnych i państwowych z częścią załogi ŁZPB im. Obrońców Pokoju w Łodzi, 15 II 1971 r., k. 79. 
wybieranych do rady zakładowej i robotniczej, zapłata za czas strajku na podstawie dotychczasowych średnich zarobków, obniżenie wieku emerytalnego dla wszystkich pracowników: kobiety - 55 lat, mężczyźni - 60 lat, a zwłaszcza dla tych, „którzy pracują w szczególnie ciężkich warunkach”, zrównanie zasiłków chorobowych pracowników fizycznych z umysłowymi, wyjaśnienie, „dlaczego Łódź jako drugie miasto po stolicy pozostawia wiele do życzenia pod względem zarobków, komunikacji, budownictwa, zaopatrzenia sklepów w tańsze artykuły żywnościowe" ${ }^{45}$.

Tymczasem Jaroszewicz i inni przedstawiciele władz centralnych w pierwszym rzędzie usiłowali tłumaczyć istniejacca sytuację swoją niewiedzą i zaniedbaniami poprzedniej ekipy (,wiecie przecież, że Gomułka nie pozwalał rozwijać przemysłu lekkiego"). Wykazywano zrozumienie dla dążenia robotników do poprawy swojej sytuacji bytowej (,My Polacy nie jesteśmy już tymi z [19] 45 r. Już się nie możemy zadowalać bochenkiem chleba") i kolejny raz zapewniano ich, że nowe kierownictwo nie użyje siły, aby stłumić strajk. Do tego dochodziło wyjaśnianie rozmaitych nieporozumień i plotek o podwyżkach dla stoczniowców czy milicji. Tego rodzaju kwestie wywoływały szczególnie duże emocje. Stwierdzenie premiera, że rząd musi przeznaczyć z budżetu pewne kwoty na rolnictwo, aby zwiększyć produkcję deficytowego na rynku mięsa, spotkało się z krytycznymi uwagami: „Po co? Chłopi i tak mają dobrze” oraz „Mięso w kraju jest, tylko nogi ma za granicę ucieka”. Podobnie tłumaczenie przez Jaroszewicza pogłoski, że dyrektorzy w Polsce nie zarabiają miesięcznie 100 tys. zł, a najwyżej 17 tys. (dyrektor Kombinatu Metalurgicznego Huta im. Lenina), wywołało głośne niezadowolenie jednej z robotnic: „Mój Boże - tyle co ja za cały rok zarabiam". Wszystkie argumenty podnoszone przez członków delegacji partyjno-rządowej miały przekonać strajkujacych, że w chwili obecnej nie było możliwe spełnienie ich zasadniczego postulatu płacowego. Te pożądane zmiany powinny jednak nastapić w nieodległej przyszłości (,czasu nam potrzeba, czasu"), stąd ponawiana prośba o okazanie zaufania nowej ekipie rządzącej. Ten motyw nie trafiał jednak do robotników. Jeden z nich odpowiedział premierowi wprost: „Jak my możemy wam wierzyć, jak żeście 15 lat nas kłamali?". A inny skomentował uwagi Jaroszewicza o sytuacji gospodarczej w kraju nie mniej bezceremonialnie: „Nie umiecie zaradzić, bo nie umiecie gospodarować" ${ }^{46}$.

Dodać można, że w konfrontacji ze wzburzonymi robotnikami i robotnicami, ich emocjonalnymi wypowiedziami, z których część kończyła się płaczem, premier Jaroszewicz słabo sobie radził. Pod koniec spotkania na oddziale wykończalni ŁZPB sięgnął więc nawet do wątków osobistych. Mówił, że gdy w 1945 r.

\footnotetext{
45 APŁ, KŁ PZPR, 1892, Postulaty pracowników fizycznych ŁZPB im. Obrońców Pokoju, 14 II 1971 r., k. 151.

${ }^{46}$ Ibidem, Spotkanie w tkalni „C” ŁZPB im. Obrońców Pokoju, 14/15 II 1971 r., k. 152-156; ibidem, Spotkanie w wykończalni, [15 II 1971 r.], k. 158.
} 
„szedł z karabinem przez Łódź”, to nie myślał, iż w przyszłości w tym samym mieście znajdzie się $\mathrm{w}$ tak trudnej sytuacji. Zauważył też, że „nie rwał się na stanowisko i na pewno na nim tak długo jak jego poprzednik [Józef Cyrankiewicz - K.L.] nie będzie. Ja mam 62 lata - mówił - ja przy takim tempie pracy i przy takim ogromie spraw trudnych nie pociagnę dłużej niż dwa lata" ${ }^{47}$. Poza tym kolejny raz chciał się podeprzeć autorytetem Gierka, podkreślając, że wszystkie zapewnienia o poprawie sytuacji w przemyśle lekkim maja jego akceptację. Wspomniał też o „serdecznych pozdrowieniach” dla robotników łódzkich. To i inne wezwania pozostały jednak bez odpowiedzi oczekiwanej przez premiera. Jedna z robotnic rozkładając ręce, powiedziała: „Co wy kobitki wita $z$ tego?”, a inna dodała: „Mamy pozdrowienia ale nie mamy forsy” ${ }^{48}$. Te zabarwione gorzką ironią słowa należy uznać za ostateczne podsumowanie nieudanego pobytu premiera Jaroszewicza w ogarniętej strajkiem Łodzi.

Po serii wieczornych i nocnych spotkań stanowisko władz partyjno-rządowych niezmiennie było krańcowo inne od tego, jakie zajmowali strajkujący robotnicy. Wyjeżdżając z Łodzi, premier Jaroszewicz wiedział, że trzeba spełnić żądanie płacowe strajkujących lub wycofać się z podwyżek cen ${ }^{49}$. Do podjęcia decyzji dodatkowo mobilizował rządzących fakt, że w poniedziałek 15 II 1971 r. kryzys w Łodzi zaczął się pogłębiać. O ile w Szczecinie i Gdańsku - jak pisał Michał Paziewski - w trakcie spotkań z Gierkiem robotnicy odczuwali powiew nowego stylu sprawowania władzy i przeżywali wręcz pewne uniesienie, wypływające $\mathrm{z}$ dowartościowania ich przez sam fakt bezpośrednich rozmów z I sekretarzem, to w Łodzi nastroje były krańcowo odmienne ${ }^{50}$. Od rana do strajku przyłączyło się 20 nowych zakładów, co istotne - większość spoza branży włókienniczej. Dalszy rozwój wydarzeń był nie do przewidzenia. To mógł być początek trzeciej fali strajków w Polsce (po tych z grudnia 1970 i stycznia $1971 \mathrm{r}$. $)^{51}$. W istniejących realiach dla władz nie było innej drogi jak ustępstwa. Nie chcąc wywołać lawiny żądań płacowych, co mogłoby spowodować podniesienie płac tylko dla włókniarzy, wieczorem 15 lutego ogłoszono komunikat rządu, że z dniem 1 marca ceny artykułów żywnościowych zostaną obniżone do poziomu sprzed grudnia 1970 r. Fakt ten oznaczał, że włókniarze łódzcy osiagnęli swój cel, a premier Jaroszewicz musiał się pogodzić z porażką w roli negocjatora. W efekcie już nigdy nie podją się on takiej misji.

${ }^{47}$ Ibidem, Spotkanie w wykończalni, [15 II 1971 r.], k. 159.

${ }^{48}$ K. Lesiakowski, Strajki robotnicze..., s. 305.

${ }^{49}$ P. Jaroszewicz, B. Roliński, op. cit., s. 171.

${ }^{50}$ M. Paziewski, op. cit., s. 73.

51 Takie określenie pojawiło się np. w materiałach Centralnej Agencji Wywiadowczej, które z data 17 II 1971 r. trafily na biurko prezydenta USA Richarda Nixona. Zob. https://www. cia.gov/library/readingroom/docs/DOC_0005992485.pdf (dostęp: 11 IX 2019); P. Perzyna, Strajki w mieście wtókniarek w lutym 1971 r., „Biuletyn Instytutu Pamięci Narodowej” 2018, nr 6, s. 92. 
Strajki z lutego 1971 r. i przebieg rozmów z szefem rządu PRL Jaroszewiczem dowodza, iż włókniarze byli mocno rozczarowani polityką władz wobec swojej branży. Ich determinacja okazała się tak duża, że ekipa gierkowska musiała skorygować swoją politykę. Sukces negocjacyjny rządzacych, odniesiony w Szczecinie i Gdańsku, nie wystarczył, aby zapanować nad sytuacją w Łodzi. Nie wiadomo jednak, czy gdyby w tym mieście pojawił się Gierek, cieszący się wtedy dużym poparciem wśród Polaków, efekt łódzkich spotkań byłby taki sam. Z pewnością rozmowy miałyby inną dynamikę, ale to nie gwarantowało pożądanego przez władzę finału. Po niepowodzeniu wyjazdu Jaroszewicza, Szydlaka, Kulińskiego i innych reżim nie miał innej alternatywy niż odejście od podwyżek cen. W ustępstwie tym zawierać się będzie jednak zalążek kolejnego kryzysu, gdyż sparaliżowało ono na lata decyzje rządzących w sferze płac, co w konsekwencji stało się jednym z czynników rozregulowania polskiej gospodarki ${ }^{52}$. A to daje podstawę do stwierdzenia, że włókniarze z „czerwonej Łodzi” strajkiem z 1971 r. i nieugięta postawą $\mathrm{w}$ rozmowach $\mathrm{z}$ Jaroszewiczem pośrednio przyczynili się do osłabienia panowania komunistów. Jednocześnie mieli też swój udział w stopniowym utrwaleniu się w kręgach władzy refleksji, że wielkiego konfliktu społecznego nie uda się rozwiązać innymi środkami niż polityczne. Na praktyczne zastosowanie tego wniosku trzeba było jednak poczekać do $1980 \mathrm{r}$.

\section{Streszczenie}

Zjawiska kryzysowe były immanentną cechą rzeczywistości PRL. Z fazy ukrytej okresowo przechodziły one fazę kryzysu jawnego. Przez długie lata nie wypracowano jednak racjonalnego sposobu rozwiazywania ostrych sytuacji konfliktowych. Przez ćwierć wieku jedyna metodą była próba pokonania zrewoltowanego społeczeństwa, a w praktyce jakiegoś jego segmentu, z wykorzystaniem sił aparatu przemocy. Dopiero bunt polskich robotników z przełomu 1970 i 1971 r. przyniósł zapowiedź zmiany. O ile w pierwszym okresie, tzn. w grudniu 1970 r. na szeroką skalę użyto jeszcze sił porządkowych i wojska, co skutkowało dziesiątkami ofiar śmiertelnych, to nowa ekipa rządząca z Edwardem Gierkiem na czele w styczniu 1971 r., w obliczu następnej fali strajków robotniczych, sięgnęła po kompromis jako narzędzie rozwiązywania sytuacji konfliktowej. Bezpośrednie spotkanie Gierka z reprezentantami strajkujących w Szczecinie, a potem w Gdańsku pokazało, że było to trafne posunięcie. Jednak nowe strajki, które wybuchły w Łodzi 10 II 1971 r., dowiodły, że nawet seria rozmów wysokich przedstawicieli władz państwowych z mocno niezadowolonymi robotnikami nie jest gwarancją porozumienia i zakończenia konfliktu. W szczytowym momencie strajku w Łodzi od maszyn odeszło 60 tys. osób. Czując swoją siłę, strajkujący nie zamierzali ustapić z zasadniczego żądania - podniesienia płac lub wycofania się rządu z grudniowej podwyżki cen. Ich determinacja ostatecznie dała oczekiwany efekt. Wieczorem 15 lutego ogłoszono komunikat, że Rada Ministrów postanowiła obniżyć ceny artykułów

52 S. Dzięcielska-Machnikowska, G. Matuszak, Eódź między grudniem 1970 roku a lutym 1971 roku, „Rocznik Łódzki” 1983, t. XXXIII, s. 227. 
żywnościowych do poziomu sprzed grudnia 1970 r. Zwycięstwo łódzkich włókniarzy wywarło duży wpływ na sytuację w Polsce w kolejnych latach, w tym na stopniowe utrwalenie się w kręgach władzy przekonania, że wielkiego konfliktu społecznego nie uda się rozwiąać innymi środkami niż polityczne.

\section{No agreement. A Stormy Meeting of the Łódź Striking Textile Workers with Prime Minister Piotr Jaroszewicz in February 1971}

Crisis phenomena were an inherent feature of the reality in the Polish People's Republic. Usually, they stayed in the hidden phase, and only occasionally became overt. For a long time, however, no rational method of solving acute crises was developed. For twenty-five years, the only way to solve a problem was an attempt to crush the revolted society; in practice, it was usually its segment, by force with the use of the apparatus of violence. Only the rebellion of Polish workers at the end of 1970 and in early 1971 heralded a change in this regard. In the first period, i.e. in December 1970, security and military forces were still used on a large scale, which resulted in dozens of deaths. However, in January 1971, a new ruling team with Edward Gierek at the lead, in the face of the next wave of workers' strikes, decided to seek a compromise. Gierek's personal meeting with the representatives of the strikers in Szczecin, and then in Gdańsk, proved that it was the right move. New strikes, however, that broke out in Łódź on 10 February 1971 proved that even a series of talks between high representatives of the state authorities and deeply dissatisfied workers did not guarantee an agreement and an end to the conflict. At the peak of the strike in Łódź, 60,000 people left the machines. Aware of their strength, the strikers did not intend to resign from their fundamental demand of a salary raise or of the government's withdrawal from the December increase in prices. Their determination finally brought the expected effect. It was announced in the evening of 15 February that the Council of Ministers decided to lower the food prices to the level from before December 1970. The victory of Łódź textile workers had a significant influence on the situation in Poland in the following years, including the gradual consolidation within the power circles of the opinion that a great social conflict cannot be solved by means other than political.

\section{Bibliografia}

Coleman P.T., Konflikt a władza, w: Rozwiazywanie konfliktów. Teoria i praktyka, red. M. Deutsch, P.T. Coleman, tłum. M. Cierpisz i in., Kraków 2005, s. 108-128.

Dahrendorf R., Klasy $i$ konflikt klasowy w społeczeństwie przemysłowym, tłum. R. Babińska, Kraków 2008.

Drygalski J., Kwaśniewski J., (Nie)realny socjalizm, Warszawa 1992.

Dzięcielska-Machnikowska S., Matuszak G., Łódź między grudniem 1970 roku a lutym 1971 roku, „Rocznik Łódzki” 1983, t. XXXIII.

Eisler J., Grudzień 1970. Geneza, przebieg, konsekwencje, Warszawa 2000.

Kamiński Ł., Polacy wobec nowej rzeczywistości 1944-1948. Formy pozainstytucjonalnego, żywiołowego oporu spotecznego, Toruń 2000.

Kenney P., Budowanie Polski Ludowej. Robotnicy a komuniści 1945-1950, tłum. A. Dzierzgowska, Warszawa 2015.

Kulesza W., Demonstracja. Blokada. Strajk (Granice wolności zgromadzeń i strajku w polskim prawie karnym na tle prawa niemieckiego), Łódź 1991.

Lesiakowski K., Strajki robotnicze w Łodzi 1945-1976, Łódź 2008.

Łuczak A., Dekada polskich przemian. Studium władzy i opozycji, Warszawa 2012. 
Matys M., Kto pokazat tyłek Jaroszewiczowi?, w: P. Lipiński, M. Matys, Absurdy PRL-u, Warszawa 2014, s. 37-38.

Mołdawa T., Ludzie władzy 1944-1991. Władze państwowe i polityczne Polski według stanu na dzień 28 II 1991, Warszawa 1991.

Nowak S., O Polsce i Polakach, Warszawa 2009.

Perzyna P., Strajki $w$ mieście wtókniarek $w$ lutym 1971 r., „Biuletyn Instytutu Pamięci Narodowej" 2018, nr 6.

Świderski B., Gdańsk i Ateny. O demokracji bezpośredniej w Polsce, Warszawa 1996.

Touraine A., O socjologii, tłum. M. Warchała, Warszawa 2010.

Wojtaszak A., Konflikt i jego znaczenie w aspekcie politologicznym, w: Oblicza konfliktów. Zbiór analiz i studia przypadków, red. J.J. Piątek, R. Podgórzańska, Toruń 2008, s. 321-328.

Krzysztof Lesiakowski - dr hab., pracownik Uniwersytetu Łódzkiego, Wydział Filozoficzno-Historyczny. Jego zainteresowania naukowe koncentrują się na biografistyce polskiej XX w., relacjach między władzą a społeczeństwem w powojennej Polsce, polityce komunistycznego państwa wobec młodego pokolenia oraz dziejach regionu łódzkiego. E-mail: krzysztof.lesiakowski@uni.lodz.pl.

Krzysztof Lesiakowski - dr hab., employee of the University of Łódź, Faculty of Philosophy and History. His research interests focus on the studies of Polish biographies of the 20th century, relations between the state authorities and society in post-war Poland, the communist state's policy towards the young generation and the history of the Łódź region. E-mail: krzysztof.lesiakowski@uni.lodz.pl. 